\title{
Bimtek Pengadaan Pupuk Organik Plus in Situ Di Desa Nyur Lembang Kecamatan Narmada Kabupaten Lombok Barat- NTB
}

\author{
Zaenal Arifin*, Lolita Endang Susilowati, Mansur Ma'shum \\ Program Studi Ilmu Tanah, Fakulas Pertanian, Universitas Mataram, Mataram, Indonesia.
}

\author{
Article history \\ Received: 15-06-2020 \\ Revised: 14-07-2020 \\ Accepted: 15-07-2020 \\ *Corresponding Author: \\ Zaenal Arifin \\ Program Studi Ilmu Tanah, \\ Fakulas Pertanian, Universitas \\ Mataram, Mataram, Indonesia \\ Email: \\ zn.arifin@yahoo.co.id
}

\begin{abstract}
This program is aimed to: (1) increase the knowledge of the target group on the excellence of organic fertilizers and the benefits of organic fertilizer plus application on vegetable cultivation; (2) provision of technical supervision in the production of organic fertilizers plus with decomposer of Pphosphorus fertilizers enriched with drought tolerant organism who increase phosphor solubility. The activity of community service was implemented in Nyur Lembang, Narmada, West Lombok, the Province of West Nusa Tenggara for six months (from April to September 2019) applying partisipatory approach. The activities were (1) extension on production of organic fertilizers and (2) training of production of organic fertilizers plus. The output are (1) increase of the partiipants'knowledge on the excellence of organic fertilizers and (2) the participants prosess skills in producing organic fertilizers plus in situ agricultural waste.
\end{abstract}

Keywords: organic fertilizers plus; drought tolerant organism; in situ

Abtrak: Kegiatan ini bertujuan untuk: (1) meningkatkan pengetahuan mitra sasaran terkait dengan keunggulan pupuk organik dan manfaat pupuk organik plus dalam budidaya sayuran organik; (2) memberikan bimbingan teknis pembuatan pupuk organik plus dengan dekomposer pupuk hayati $\mathrm{P}$ beragensia bakteri pelarut fosfat toleran kekeringan. Kegiatan pengabdian pada masyarakat ini dilaksanakan dalam kurun waktu enam bulan (dari bulan april sampai september 2019) di Desa Nyur Lembang Kecamatan Narmada Kabupaten Lombok Barat. Dalam kegiatan ini, pendekatan yang digunakan terhadap mitra sasaran adalah pendekatan partisipatif dimana mitra sasaran tidak saja sebagai obyek tetapi juga sebagai subyek kegiatan. Bentuk kegiatan pengabdian yang diterapkan adalah (1) penyuluhan tentang pembuatan pupuk organik dan keunggulan bertanam sayuran dengan menggunakan pupuk organik, dan (2) pembelajaran langsung melalui kegiatan bimtek pembuatan pupuk organik plus dengan dekomposer pupuk hayati $\mathrm{P}$ beragensia bakteri pelarut fosfat. Hasil atau luaran dari kegiatan pengabdian ini adalah (1) mitra sasaran memiliki peningkatan penguasaan pengetahuan tentang keunggulan pertanian organik dan manfaat pupuk organik plus dalam budidaya sayuran organik; (2) mitra sasaran menguasai teknik pembuatan pupuk organik plus berbahan limbah pertanian in situ.

Kata Kunci: pupuk organik plus; mikroorganisme toleran kekeringan; in situ 


\section{PENDAHULUAN}

Di lokasi sasaran kegiatan pengabdian yaitu di Desa Nyur Limbang Kecamatan Narmada Kabupaten Lombok Barat merupakan daerah yang kaya dengan air sehingga budidaya ikan dalam tambak menjadi salah satu usaha mata pencaharian, selain bentuk usaha lainnya seperti bertani, berdagang dan lainnya. Masyarakat yang mengusahakan budidaya ikan tawar baik sebagai mata pencarian utama atau sampingan, secara periodik ketika panen akan melakukan pengurasan, pengerukan sedimen (endapan) di dasar kolam dan pengeringan. Hal ini dimaksudkan untuk menjaga kondisi kolam agar tetap baik terutama menjaga salinitas dan $\mathrm{pH}$ tidak terlalu masam pada pemeliharaan ikan berikutnya. Limbah perikanan berupa sedimen tersebut biasanya hanya dilonggokkan di pinggir kolam dan belum banyak dimanfaatkan.

Ketersediaan air yang cukup dimanfaatkan oleh petani untuk menerapkan pola tanam padi padi- palawija/sayuran atau petani yang mempunyai lahan kurang luas dapat menanam sayuran sepanjang tahun. Ketika panen padi akan menghasilkan limbah pertanian berupa jerami dalam jumlah yang banyak. Kebanyakan petani memiliki budaya membakar jerami atau memanfaatkannya untuk pakan ternak daripada mengelolanya sebagai sumber bahan organik in situ. Kegiatan ini sudah berjalan secara terus-menerus, sebagai akibatnya terjadi pemiskinan bahan organik tanah. Tanah yang miskin bahan organik akan menurunkan kemampuan tanah dalam mengefisiensikan pemupukan anorganik sehingga kebutuhan pupuk dari tahun ketahun semakin meningkat. Selain itu, pembakaran jerami dapat mengakibatkan keseimbangan hayati dalam ekosistem tanah, dimana parasit dan predator yang berfungsi sebagai musuh alami hama dan penyakit dalam tanah akan mati. Selain itu mikroba yang berfungsi dalam perombakan bahan organik, penambat nitrogen dan mikrobia lain yang memiliki fungsi biologis bagi pertumbuhan tanaman akan mengalami penurunan populasi (Makarim dkk, 2007). Anjuran untuk mengembalikan jerami ke tanah sawah menemui beberapa kendala. Umumnya petani membakar jerami karena beberapa alasan, antara lain mengejar waktu tanam, jerami mengganggu proses pengolahan tanah dan pembakaran jerami tidak perlu biaya. Bila indeks pertanaman tiga kali, petani tidak cukup waktu untuk mengomposkan jerami. Sementara, pengembalian jerami segar ke tanah sawah yang segera ditanami tidak dianjurkan karena akan menghambat pertumbuhan tanaman awal akibat immobilisasi hara $\mathrm{N}$ dan $\mathrm{P}$ oleh mikroorganisme tanah (Fontaine et al., 2003). Oleh karena itu, jerami harus dikomposkan terlebih dahulu.

Terkait dengan ketersediaan limbah perikanan dan pertanian di lokasi sasaran yang berlimpah merupakan bahan baku yang potensial untuk dijadikan pupuk organik melalui proses pengomposan. Limbah perikanan merupakan material organik yang kaya dengan nutrisi tanaman sehingga sangat sesuai untuk bahan baku pupuk organik kompos. Menurut SNI 19-7030-2004 batasan kompos adalah bentuk akhir dari bahan-bahan organik sampah domestik setelah mengalami dekomposisi. Dekomposisi adalah perubahan komposisi bahan organik limbah akibat penguraian oleh mikroorganisma pada suhu tertentu menjadi senyawa organik yang lebih sederhana ((SNI: 19-70302004). Selanjutnya kematangan kompos ditunjukkan oleh hal-hal berikut: 1) C/N - rasio mempunyai nilai (10-20): 12 ) suhu sesuai dengan dengan suhu air tanah 3) bewarna kehitaman dan tekstur seperti tanah 4) berbau tanah (SNI: 19-7030-2004).

Terkait dengan pembuatan pupuk organik kompos plus dapat dilakukan dengan memanfaatkan pupuk hayati P beragensi bakteri pelarut fosfat (Arifin dan Lolita, 2018) sebagai dekomposer. Keuntungan dari penggunaan dekomposer pupuk hayati $\mathrm{P}$ adalah tidak saja proses dekomposisi bahan organik yang berlangsung relatif cepat, tetapi juga ketersediaan $\mathrm{P}$ asal senyawa $\mathrm{P}$ - 
organik juga lebih tinggi. Dengan demikian kebutuhan tanaman akan unsur P segera terpenuhi. Pada awal-awal pertumbuhan unsur $\mathrm{P}$ berguna untuk merangsang pertumbuhan akar tanaman. Perkembangan akar yang lebih baik akan meningkat proses penyerapan hara tidak saja hara $\mathrm{P}$ tetapi juga hara makro lainnya. Mengacu pada uraian di atas, maka bimtek pembuatan pupuk organik plus sangat tepat dilaksanakan di lokasi sasaran dan bermitra dengan ibu-ibu PKK Desa Nyur Lembang. Program ini sejalan dengan program desa tentang rumah pangan lestari (RPL).

\section{METODE}

Kegiatan pengabdian pada masyarakat ini dilaksanakan dalam kurun waktu enam bulan di Desa Nyur Lembang Kecamatan Narmada Kabupaten Lombok Barat. Terhadap mitra sasaran digunakan pendekatan partisipatif dalam kegiatan ini. Mitra sasaran terlibat secara aktif dalam penggalian gagasan, pengambilan keputusan mulai dari tahap persiapan, pelaksanaan sampai dengan evaluasi pelaksanaan kegiatan. Bentuk kegiataanya adalah (1) penyuluhan dan (2) pembelajaran langsung melalui kegiatan bimtek pembuatan pupuk organik Plus. Pada kegiatan ini mitra sasaran tidak hanya sebagai obyek tetapi juga langsung menjadi pelaku kegiatan, sedangkan tim pengabdian bertindak sebagai fasilitator. Tim pengabdian dan mitra sasaran membangun komitmen bersama sesuai dengan peran masing-masing untuk mencapai target dan luaran kegiatan. Bagi tim pelaksana pengabdian, kegiatan pengabdian pada masyarakat ini dapat dijadikan sarana untuk mengiplemtasikan ilmu pengetahuan guna memperkuat pilar keilmuan ketika memberikan pengajaran di perguruan tinggi.

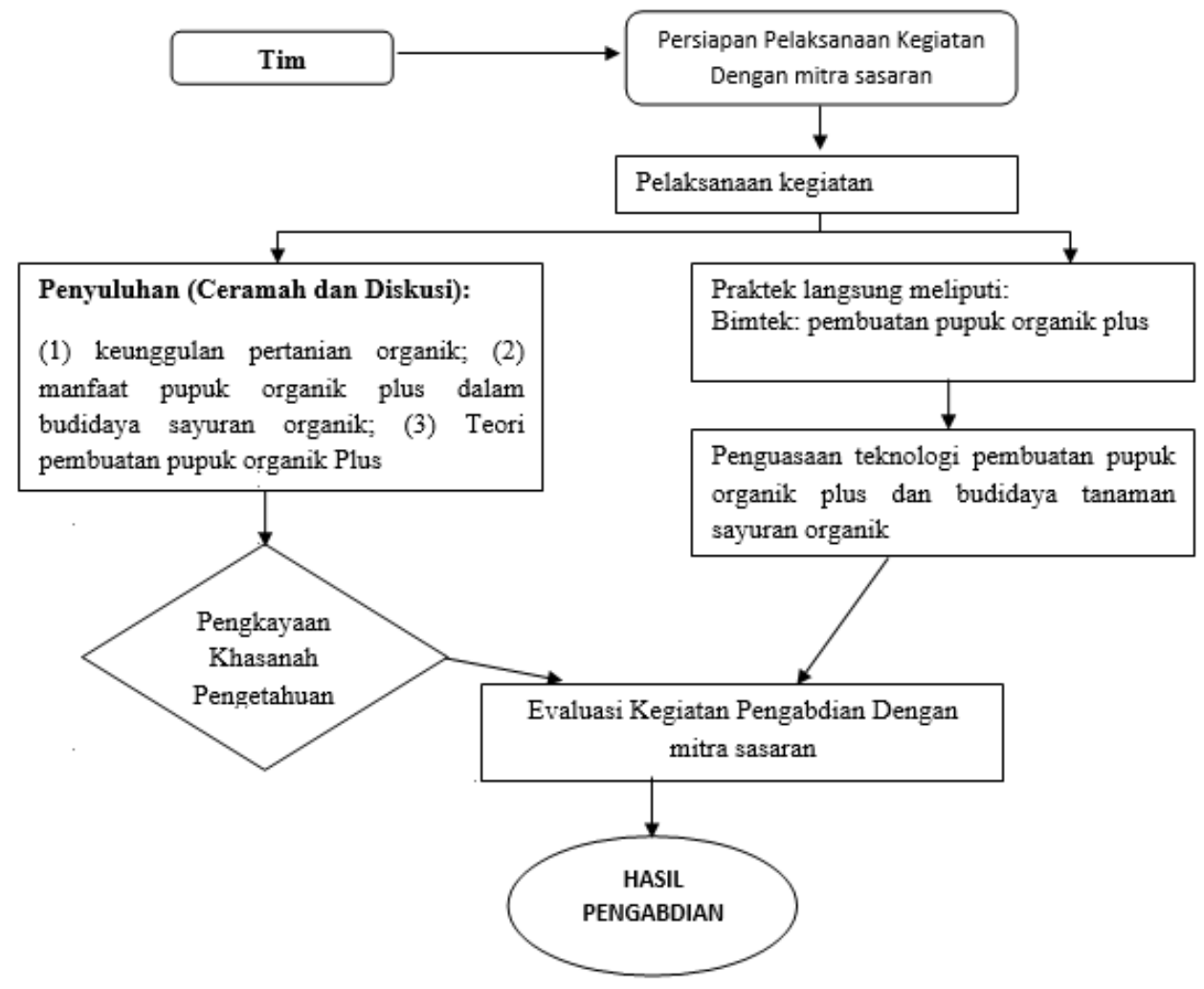

Gambar 1. Alur Pelaksanaan Kegiatan Pengabdian 
Tahapan operasional dari kegiatan ini disajikan dalam Gambar 1 dan dijabarkan dalam perencanaan pelaksanaan kegiatan sebagai berikut:

\section{Persiapan dan Pelaksanaan Pengabdian kepada Petani}

- Tim pengabdian dan mitra sasaran (diwakili oleh 3 orang kader) melakukan pertemuan dengan agenda "persiapan pelaksanaan kegiatan pengabdian meliputi (i) bagaimana kegiatan itu dilakukan; (ii) penetapan waktu pelaksanaana; (iii) penetapan tempat-tempat pelaksanaan kegiatan; (iv) bentuk tanggung jawab dan komitmen untuk melaksanakan kegiatan ini. Tahap kegiatan ini dimaksudkan untuk menumbuhkan rasa tanggungjawab mitra sasaran atas terlaksananya kegiatan bersama ini dalam rangka mencapai target dan luaran kegiatan sebagaimana yang dikemukakan di atas.

- Kegiatan penyuluhan dengan metode ceramah dan diskusi yang diikuti oleh seluruh anggota mitra sekitar 20 orang. Kegiatan ini bertujuan untuk memperkaya khasanah pengetahuan mitra sasaran tentang (1) keunggulan pertanian organik; (2) manfaat pupuk organi plus dalam budidaya sayuran organik dan (3) Teori pembuatan pupuk organik Plus

- Kegiatan praktek langsung dengan kegiatan: bimbingan teknis pembuatan pupuk organik dengan menggunakan pupuk hayati $\mathrm{P}$ beragensia bakteri pelarut fosfat sebagai decomposer;

\section{HASIL DAN PEMBAHASAN}

\section{Konfirmasi Rencana Pelaksanaan Kegiatan}

Konfirmasi dan koordinasi terkait dengan rencana pelaksanaan kegiatan disampaikan kepada kepala desa Desa Nyur Lembang Kecamatan Narmada Kabupaten Lombok Barat yang dilaksanakan di kantor kepala desa, dihadiri oleh Petugas Petani Lapangan (PPL) desa Nyur Lembang, Ibu Ka PKK, pengurus PKK, Ketua Kelompok Tani, dan tim pengabdian. Hasil pertemuan adalah sebagai berikut: (1) ditetapkan Dusun Nyur Lembang sebagai lokasi sasaran penyuluhan; (2) ditetapkan kelompok sasaran adalah anggota kelompok tani pengembang tanaman hortikultura di dusun Nyur Lembang; (3) disepakati jadwal kegiatan.

Penetapan Dusun Nyur Lembang sebagai lokasi sasaran didasarkan pada beberapa pertimbangan, diantaranya: (1) warga dusun, khususnya anggota kelompok tani yang aktif membudidayakan tanaman buah dan sayuran dianggap sangat perlu ditingkatkan pengetahuan tentang tehnik pembuatan kompos plus dengan memanfaatkan limbah perikanan dan jerami padi agar dapat memenuhi kebutuhan pupuk organik sendiri. Selama ini, untuk memenuhi kebutuhan pupuk organik didatangkan dari luar desa atau kelompok tani yang lain; (2) umumnya para petani yang tergabung dalam kelompok tani pengembang tanaman sayuran dan buah-buahan mempunyai motivasi dan semangat yang tinggi untuk maju; (3) Lokasi tempat pelaksanaan kegiatan sangat memadai dimana terdapat balai pertemuan kelompok di rumah kepala dusun yang juga merupakan ketua kelompok tani.

\section{Sosialisasi Kegiatan}

Acara sosialisasi dihadiri oleh warga kelompok tani di Dusun Nyur Lembang, Kepala Desa, anggota kelompok tani, dan anggota tim pengabdian. Acara dibuka oleh kepala Desa dan dilanjutkan dengan pemaparan rencana pelaksanaan kegiatan oleh anggota tim pengabdian mulai dari latar belakang, tujuan, manfaat dan rencana tahapan pelaksanaan kegiatan pengabdian (Gambar 2). 

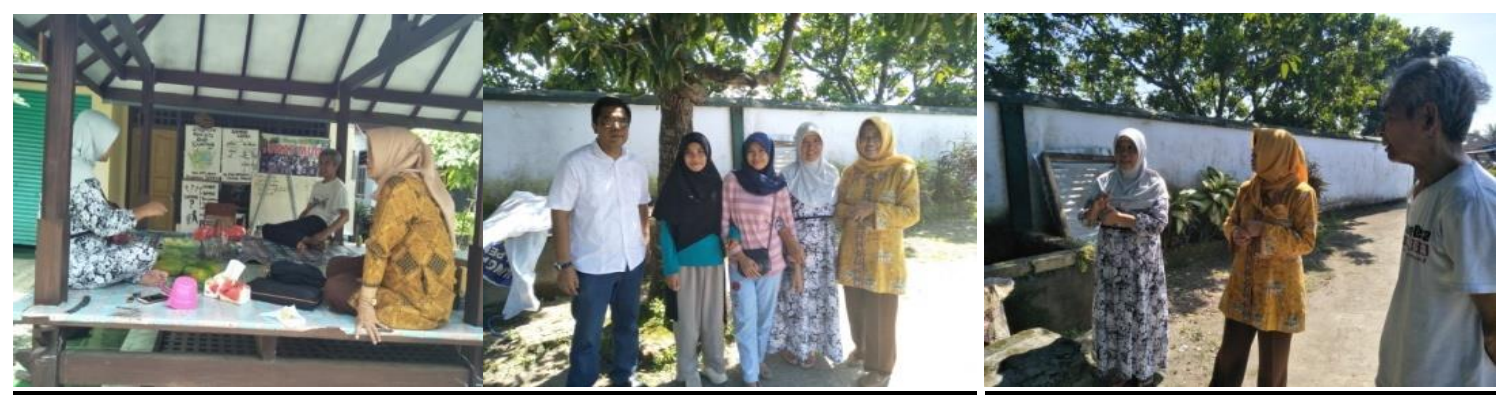

Gambar 2. Sosialisasi Kegiatan Pengabdian

Beberapa hal yang disepakati dalam pertemuan adalah sebagai berikut: adalah (1) penyuluhan tentang pembuatan pupuk organik dan organik plus serta keunggulan bertanam sayuran dengan menggunakan pupuk organik plus; (2) diperlukan penyuluhan terkait dengan peningkatan pengetahuan warga tentang sistim pertanian organik dan bimbingan tehnik pembuatan pupuk organik plus dengan menggunakan bahan baku limbah perikanan dan jerami padi; (3) jumlah peserta penyuluhan tidak terbatas, semua anggota kelompok tani dipersilahkan untuk mengikuti; (4) penyuluhan dilaksanakan setelah sholat Ashar bertempat di balai pertemuan kelompok di rumah kepala dusun Nyur Lembang pada setiap hari kamis minggu ke IV bulan Juni, minggu III dan IV bulan Juli 2017 dan praktik pembuatan pupuk organik plus minggu ke IV bulan Juni.

\section{Kegiatan Penyuluhan dan Bimbingan Tehnik Pembuatan Pupuk Organik Plus}

Kegiatan penyuluhan dilaksanakan sebanyak 3 kali pertemuan dengan tiga materi penyuluhan yaitu tentang sistim pertanian organik, budidaya sayuran organik dan pembuatan pupuk organik plus dengan dengan menggunakan pupuk hayati $\mathrm{P}$ sebagai dekomposer. Kegiatan ini dilanjutkan dengan bimbingan tehnik pembuatan pupuk organik plus melalui praktik lansung pengomposan.

Materi penyuluhan pertama yang diberikan oleh tim pengabdian adalah tentang sistim pertanian organik dengan segala keuntungan dan kelemahannya. Materi kedua adalah budidaya sayuran organik pada lahan luas dan sempit dengan menerapkan sistim pertanian bertingkat. Sedangkan materi ketiga tentang pembuatan pupuk organik plus dengan menggunakan pupuk hayati $\mathrm{P}$ sebagai dekomposer, Bahan baku yang digunakan adalah sampah rumah tangga, limbah perikanan dan jerami padi yang banyak tersedia di lokasi pengabdian. Setiap kali pertemuan dihadiri oleh sekitar 15-24 orang peserta penyuluhan.

Materi penyuluhan mendapatkan respon positif dari peserta penyuluhan. Hal ini ditunjukkan dengan keaktifan peserta pada tahap diskusi pendalaman materi. Hasil diskusi pada setiap kali pertemuan menunjukkan bahwa peserta memahami apa yang disebut dengan sistem pertanian organik dengan segala kelebihannya serta cara bercocok tanam dengan sistim organik. Pada pertemuan kedua dengan topik budidaya sayuran organik pada lahan luas dan sempit dengan menerapkan sistim pertanian bertingkat, para peserta penyuluhan dapat menerima materi yang diberikan dengan cukup baik. Hal ini dapat dilihat dari sesi diskusi yang dilakukan dimana peserta dapat menerangkan tehnik bertanam sayuran organik, bagaimana membuat media tanam sayuran organik dalam pot, dan menerangkan tehnik pemupukan dengan pupuk organik. Dalam diskusi pemahaman dan pendalaman materi tentang dampak pemberian pupuk organik untuk kesuburan dan kesehatan tanah, salah satu peserta penyuluhan memberikan penjalasan sebagai berikut: bahwa kalau melakukan pemupukan dengan kompos menyebabkan lahan pertanian menjadi gembur, mudah diolah serta tanah lebih lama menyimpan air. Demikian juga binatang tanah seperti cacing lebih tinggi populasinya. Hal ini 
menunjukkan bahwa peserta penyuluhan dapat memahami dan mengerti manfaat bahan organik bagi tanah, dimana dengan kehadiran bahan organik dapat memperbaiki sifat $\mathrm{f}$ isika, kimia, dan biologi tanah.

Pada penyuluhan ketiga dengan materi tentang pembuatan pupuk organik plus dengan menggunakan pupuk hayati $\mathrm{P}$ sebagai dekomposer, peserta penyuluhan banyak mempertanyakan arti pupuk organik plus. Dalama hal ini pemateri dengan tim penyuluh memberikan penjelasan bahwa pupuk organik plus yang dibuat dengan menggunakan dekomposer pupuk hayati $\mathrm{P}$ akan menghasilkan pupuk organik yang kaya dengan kandungan $\mathrm{P}$ tersedia. Dalam pupuk hayati P banyak mengandung bakteri perombak $\mathrm{P}$ sehingga akan meningkatkan ketersediaan $\mathrm{P}$ apabila diaplikasikan sebagai pupuk. Dengan tingginya kandungan $\mathrm{P}$ tersedia merupakan salah satu kelebihan pupuk orgaanik yang dihasilkan,

Pada kegiatan praktik pembuatan pupuk organik plus (Gambar 3.) dengan menggunakan bahan baku limbah perikanan dan jerami padi dengan perbandingan $1: 1$, kapur pertanian (20 kg/ton) dan dekomposer pupuk hayati $\mathrm{P}$ dalam bentuk cair (2,5 $\mathrm{l} / \mathrm{ton})$, dengan tahap pembuatannya sebagai berikut:

1) Siapkan tempat (terlindung dari sinar matahari langsung dan genangan air).

2) Campurkan bahan limbah perikanan dan jerami padi yang sudah dicacah $(5-10 \mathrm{~cm})$ secara merata.

3) Masukan bahan dalam bak pengomposan. Setiap lapisan bahan $30 \mathrm{~cm}$ siram dengan dekomposer pupuk hayati $\mathrm{P}$ dan kapur pertanian secara merata dengan kelembaban 40 - 60\%.

4) Tumpukan dibalik seminggu sekali dan setiap 3-4 hari siram dengan air untuk mempertahankan kelembaban,

5) Pengomposan 6-8 minggu
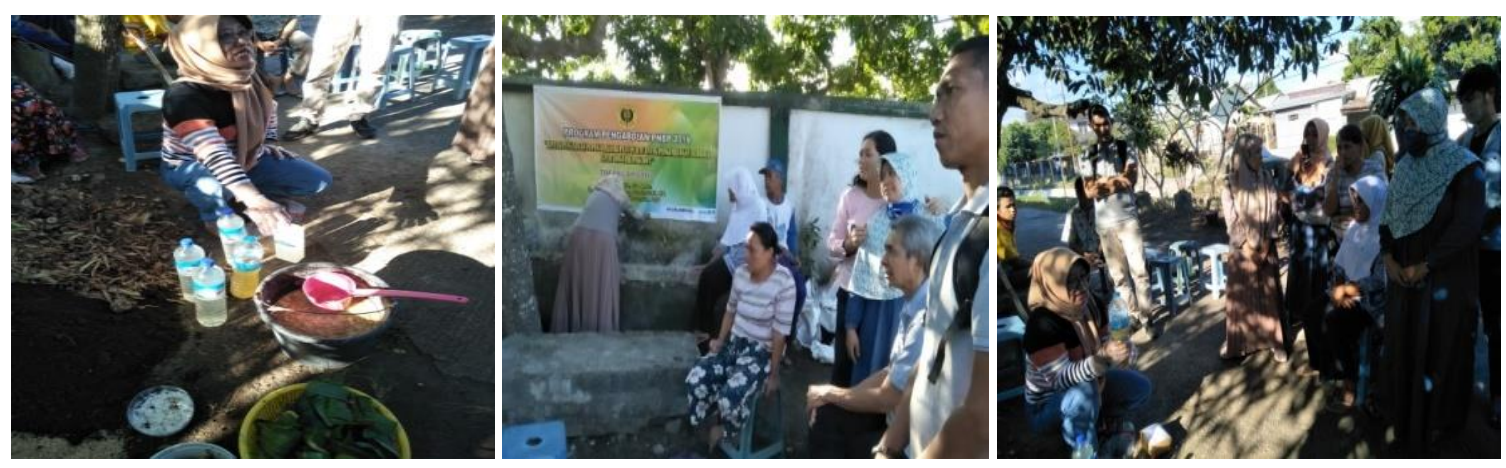

Gambar 3. Kegiatan Bimtek Pembuatan Pupuk Organik Plus

\section{Evaluasi Pelaksanaan Kegiatan}

Pada kegiatan pengabdian ini pada tahap akhir dilakukan evaluasi terhadap pelaksanaan kegiatan. Hasil evaluasi terhadap ketercapaian tujuan kegiatan dapat dikemukakan sebagai berikut: Dalam hal pengetahuan, peserta penyuluhan memberikan respon positif terhadap materi penyuluhan dan pelatihan tentang tentang 1) Sistim pertanian organik dengan segala keuntungan dan kelemahannya; 2) Bertanam sayuran organik pada lahan luas dan sempit seperti pekarangan rumah; dan 3) tehnik pembuatan pupuk organik plus dengan memanfaatkan bahan baku limbah perikanan dan jerami padi yang tersedia melimpah di lokasi kegiatan. Sebagai indikatornya adalah peserta penyuluhan menjadi tahu dan mengerti bahwa sistim pertanian organik bisa dilakukan dengan 
memanfaatkan bahan-bahan yang tersedia lokal (insitu) sebagai sumber pupuk tetapi harus dilakukan pengolahan terlebih dahulu untuk mneghasilkan pupuk matang (kompos) untuk mengurangi penggunaan pupuk pabrik. Peserta penyuluhan semakin mengerti, memahami dan menguasai tehnik pembuatan pupuk organik plus berbahan baku lokal dengan menggunakan dekomposer pupuk hayati P.

\section{KESIMPULAN DAN SARAN}

\section{Kesimpulan}

Dalam hal pengetahuan peserta penyuluhan memperlihatkan adanya peningkatan pengetahuan tentang 1) Sistim pertanian organik; 2) Bertanam sayuran organik pada lahan luas dan sempit seperti pekarangan rumah; 3) Tehnik pembuatan pupuk organik dan 4) tehnik pembuatan pupuk organik plus dengan memanfaatkan bahan baku limbah perikanan dan jerami padi yang tersedia melimpah di lokasi kegiatan. Adanya keinginan untuk maju dari kelompok sasaran. Hal ini terlihat dari semangat yang tinggi dari peserta untuk mengikuti semua kegiatan pengabdian. Kegiatan pengabdian ini mendapat respon positif dan terjadi kerjasama yang baik antara tim pengabdian, kelompok sasaran, masyarakat, dan aparat di desa Nyur Lembang sehingga tujuan kegiatan ini dapat tercapai.

\section{Saran}

Kegiatan pengabdian tentang bimbingan tehnik pembuatan pupuk organik plus sangat perlu dilakukan juga ditempat lain sehingga semakin banyak petani yang dapat memproduksi pupuk organik plus dengan memanfaatkan bahan baku in situ.

\section{Ucapan Terima Kasih}

Penulis mengucapkan terima kasih kepada Rektor Universitas Mataram yang telah memberikan dukungan financial terhadap kegiatan pengabdian ini melalui sumber dana DIPA BLU (PNBP) Universitas Mataram Tahun Anggaran 2019.

\section{DAFTAR PUSTAKA}

Arifin, Z. dan Lolita, E.S., 2018. Formulasi konsorsium BPF-indigenos sebagai agen pupuk hayati P dan efikasinya dalam meningkatkan p-tersedia, serapan $\mathrm{p}$, pertumbuhan dan hasil tanaman kedelai. Lap. Penelitian. PENELITIAN STRATEGI NASIONAL INSTITUSI. Universitas Mataram.

Fontaine, S.; A. Mariotti, L Abbadie. 2003. The priming effect of organic matter: a question of microbial competition? Soil Biology \& Biochemistry 35 (2003) 837-843

SNI 19-70300-204. Spesiikasi Kompos Dari Sampah Organik Domistik. http://ciptakarya.pu.go.id/plp/upload/peraturan/SNI_Spesifikasi_Kompos_dari_Sampah_Org anik.pdf

SNI 6729: 2013.https://www.scribd.com/doc/257361650/SNI-6729-2013-Sistem-Pangan-Organik

Sutanto, R., 2002. Penerapan pertanian organik: pemasyarakatan dan pengembangannya. Kanisius. Yogyakarta. 219 Hal.

Purnamawati, Y., 2017. Kajian Konsentrat Protein Ulat Hongkong (Tenebrio molitor L) Sebagai Bahan Pakan Sumber Protein Pengganti Meat Bone Meal Pada Broiler. Tesis. Sekolah Pascasarjana Institut Pertanian Bogor. 